\title{
Prevalence and contextual determinants of intimate partner violence in Nigeria
}

\author{
Kolawole Azeez Oyediran ${ }^{1}$ \& Bamikale Feyisetan ${ }^{2}$
}

\author{
1John Snow Inc./MEASURE Evaluation, Suite 16, 1616 N. Fort Myer Drive \\ Arlington, VA 22209, USA \\ kboyediran@gmail.com \\ ${ }^{2}$ Office of Population and Reproductive Health, Bureau for Global Health \\ USAID/Washington, DC, USA \\ kalefeyisetan@yahoo.com
}

\begin{abstract}
Multilevel logistic regression model was used to examine underlying factors influencing women's exposure to intimate partner violence (IPV) in Nigeria. The findings show that 15.2 percent of married or cohabiting women in the survey reported to experience IPV in the year preceding the 2013 Nigeria Demographic and Health Survey (NDHS). The likelihood of a Nigerian woman experiencing IPV in the year preceding the survey was shown to be significantly associated with a range of demographic, household and societal factors, including her age, spousal age difference, type of marital union, the woman's education, number of living children, religion, ethnicity and region of residence. The analysis also shows that gender normative values, women's status and community level factors have independent and incremental influence on the odds of women experiencing IPV. Ending domestic violence requires commitment to changing societal norms that promote wife beating and forced sex. Programs should be implemented to re-orientate community members to embrace gender equity, amiable spousal discussion of family issues and mutual respect.
\end{abstract}

Keywords: Nigeria, Women, Community, Intimate Partner Violence, multilevel

\section{Introduction}

\section{Background}

Violence against women has been noted to be a public health problem throughout the world $(\mathrm{WHO}$, 2005) due to its acute assault related morbidity and mortality as well as its longer term impact on women's health, including chronic pain, gynecologic problems, sexually transmitted diseases, depression, post-traumatic stress disorder, and suicide (Decker, et. al., 2009; MacQuarrie, et. al., 2013). The dimensions of domestic violence in sub-Sahara Africa countries, including Nigeria, are physical, psychological and sexual. Domestic violence is often considered an acceptable behavior in many African societies, and where it is disapproved; women are often blamed for inciting men to engage in it (Odimegwu, 200I; Okemgbo, et. al., 2002; Oyediran and Isiugo-Abanihe, 2005). For example, among the Luhya community in western Kenya and Tiv-speaking people of Nigeria, wife beating is regarded as a sign of love which women have been socialized to accept (Odimegwu, 200I; Kiragu, 1995). . Also, in many Nigerian societies there is a deep-rooted belief that a husband may censure his wife by beating her http://aps.journals.ac.za
(Okemgbo, et. al., 2002). Traditional attitudes regarding the subordination of women exacerbate problems of sexual and domestic violence (Ondicho, 2002). Viewed from different perspectives, violence against women is one of the obvious reflections of the low position and status of women in many cultures.

While a growing body of evidence highlights the magnitude of the problem of domestic violence in sub-Saharan Africa (Solanke, 20I4; Makayoto, et. al., 20I3), a number of scholars have also highlighted the negative impact of domestic violence on health outcomes (Emenike, et. al., 2008; Silverman, et. al., 2007). . It has been noted that the physical and emotional symptoms that women experience as a result of violence - including unwanted pregnancy, sexually transmitted diseases and HIV/AIDS infection, complications from abortion, and fear or loss of desire for sex - often last throughout their lives (Decker, et. al.; 2009; Silverman, et. al., 2007). Evidence reveals that domestic violence and rape are a significant cause of female morbidity and mortality (Plichta, 2004; Sarkar, 2008). A study using the 2003 
Kenya DHS survey found that women who reported ever experiencing physical or emotional violence were more likely to report ever experiencing a terminated pregnancy (Emenike, et. al., 2008). Another study from Bangladesh found that women who experienced physical or sexual violence were significantly more likely to also experience a pregnancy that ended in a non-live delivery (Silverman, et. al., 2007).

In Nigeria, studies reveal that significant proportions of women are physically and sexually abused (Yusuf, et. al., 20II; Linos, et al., 20l3; Oyediran and Cunningham, 2014) and that violence against women seriously endangers their health and well-being (Ononokpono and Azfredrick, 20I4; Solanke, 20I4). In Imo State, Nigeria, a study showed that three-fifths of women experienced battering during pregnancy while one in five reported having been forced to have sexual intercourse (Okemgbo, et. al., 2002). The little available data in Nigeria show that violence against women has increased over the past few years and affects all spheres of women's lives (Odimegwu, 200I).

Across sub-saharan African countries, scholars have documented a number of socioeconomic and demographic attributes that serve as risk and protective factors in domestic violence (Hindi et. Al, 2008; Yusuf et. Al.,20I I). The determinants include age (Fonck, et. al., 2005), number of children (Makayoto, et. al., 20I3), wealth and education (Makayoto, et. al., 20I3; Antai and Adaji, 20I2; Boyle, et. al., 2009). Women classified as having high status - including those with high levels of education, high level of autonomy in decision making and high control over resources - have usually been found to be more protected from the risk of domestic violence (Vyas and Watts, 2009; Boyle, et. al., 2009; Heise, 2012; Oyediran and Cunningham, 20l4). Caution must, however, be exercised in generalizing results as evidence has shown that the observed negative association between women's status and the risk of domestic violence may be context-specific as in more conservative settings, women with high autonomy may actually be at increased risk of violence (Vyas and Watts 2009, Tenkorang, et. al.,2013). Heavy consumption of alcohol or drugs either by women or men has been linked to the risk of violence (Yusuf, et. al., 20II), and a potential link between HIV status and domestic violence has also been recognized (Bensley, et. al., 2003). Another factor found to be associated with domestic violence is the childhood exposure to family violence with studies showing that children who witness family violence are more likely to become perpetrators or victims of violence in adulthood (Bensley, et. al., 2003; Linos, et al., 20I3).
Within Nigeria, studies have also shown that the age, education, place of residence, type of marital union and the level of income of women, their partners' educational level, the woman/husband's social group affiliation, women's status, autonomy and level of spousal interaction are related to the incidence, differential and prevalence of domestic violence (Odujinrin, 1993; Okemgbo, et. al., 2002; Antai, 20II; Yusuf, et. al., 20II; Linos, et. al., 20l3; Oyediran and Cunningham, 20I4). For instance, Okemgbo et. al., (2002) showed that wife battery was more pronounced in the urban area, while forced sexual relationship and female genital mutilation are more evident in the rural areas. Earlier, Odujinrin (1993) reported that women who had no formal education, those in low-income group and those working in the informal sector of the economy (petty traders) were more likely to be physically and verbally abused relative to their counterparts of higher status. Also women who approve of wife battery are more likely to report domestic violence than other women who did not approve of wife beating (Antai, 20II; Linos, et. al., 2013).

Despite the growing evidence on the prevalence of domestic violence, there is still limited understanding of the underlying factors. And despite the growing literature on the correlates of domestic violence, a complete picture of the risk factors has yet to emerge particularly in Nigeria. The understanding of domestic violence requires an analysis that goes well beyond examining the characteristics of the "victim" alone, but also requires an understanding of the household and community contexts within which violence occurs. In Nigeria, domestic violence (physical, emotional or sexual) is a serious problem that transcends social, geographical and ethnic divide (Linos, et. al., 20/3). Contextualizing the environment in which women experience violence is critical because of the existence of normative values that constrain individual behaviours through social enforcement or the sanctioning of any behaviours or practices based on implied consequences of non-compliance. It is, therefore, likely that women in communities with more receptive norms around violence would experience higher prevalence of domestic violence being perpetuated by their spouses. A number of community-based interventions are being implemented to mitigate against gender-based violence with a focus on changing norms and beliefs as a strategic approach (Michau, 2007; Usdin, et. al., 2005).

So far, only a few studies have examined the relationship between societal norms on spousal violence and women's risk of being abused, 
independent of her personal attitudes toward spousal violence (Boyle, et. al., 2009; Koenig, et. al., 2009; Linos, et. al., 20l3). Designing an effective program to address domestic violence requires more than information on the demographic and social correlates; an understanding of contextual and community factors, particularly facilitating or preventive norms, is important. Although strong anthropological evidence exists on the importance of community-level cultural and contextual variables as determinants of gender-based violence across cultures (Linos, et al, 20I3; Yusuf et. al., 20I I), there has not being a study in Nigeria that examines how contextual factors influence intimate partner violence. Consequently, an attempt is made in this paper to examine not only the prevalence and social predictors of intimate partner violence in Nigeria but also the role of contextual factors in determining the risks of intimate partner violence

\section{Data and Methods}

\section{Data}

The study used data from the 2013 Nigeria Demographic and Health Survey (NDHS). As with other NDHSs, the 2013 NDHS was a nationally representative sample survey conducted by the National Population Commission from June to October 2013. The ICF International provided technical assistance as part of the activities funded by the United States Agency for International Development through the MEASURE DHS+. The NDHS collected information on maternal health, sexual and reproductive health, and malaria among women aged 15 to 49 . In addition, information was collected on the demographic, social, and economic characteristics of these women and members of their households, gender based violence, perceived attitudes towards gender roles, exposure to messages about health care in the media, and knowledge of and attitudes toward the use of reproductive health services.

Using a three-stage stratified and multistage cluster sample designs (National Population Commission, Nigeria and ICF International, 20I4), the nationally representative survey covered both rural and urban households. Of the weighted sample of 27,749 women identified for the domestic partner violence, 19,924 currently married women or women in union who were living with their husbands/partners at the time of the survey were included in the current analysis. The excluded women consist of never married women, currently married women or women in union not living with their husbands/partners at the time of the survey and previously married women.

\section{Measures of dependent and explanatory variables Dependent variable}

The dependent variable, intimate partner violence in the twelve months preceding the survey, was created from responses to nine survey questions on husband's acts that indicate intimate partner violence. The women were asked to state whether their husbands punched them with fist, shook them, threw something at them, slapped them, twisted their arms or pulled their hairs, kicked or dragged them, threatened them with knife/gun or any other weapon, tried to choke or burn them, forced them to have sex or forced them to perform sexual acts they did not desire on them. A 'yes/no' response was expected for each of the nine questions with a 'yes' response indicating that the act took place and a 'no' response indicating that the act did not take place in the year preceding the survey. From the dichotomous 'yes/no' responses, an index representing exposure to intimate partner violence (physical or sexual) in the year preceding the survey respondents was created, with scores ranging from $0-9$. Women who scored 0 were then classified as not experiencing partner violence during the year preceding the survey while those who scored I or more were classified as having experienced some level of partner violence in the year preceding survey. Although the interviews generated information on two types of violence - physical and sexual - the two types of violence were combined in our analysis because of considerable overlap between them. A multilevel logistic regression model was used to examine the effects of contextual and individual level factors on whether women experienced intimate partner violence in the year preceding the survey.

\section{Explanatory variables}

The NDHS collected a number of individual-level variables which have been associated with domestic violence (Table I). The socioeconomic variables included in our models include the woman's education and religion, spousal age difference, household wealth index, type of marriage, number of living children, region of residence, ethnicity, exposure to media, and urban-rural residence. Childhood exposure to family violence, measured by the woman witnessing her father beat her mother has been included to determine whether that experience has any effects on the likelihood of a woman experiencing IPV later in life. Majority of the covariates aforementioned were assessed via single items. A relative index of household wealth was constructed based on interviewer-observed assets, including ownership of consumer items and dwelling characteristics; individuals were ranked on the basis of their household score and divided into quintiles 
with I being the poorest and 5 the wealthiest $20 \%$ of households.

For the gender norms related community-level variables - gender empowerment and gender equality - cluster-level (primary sampling unit) estimates were adopted. Once derived, the cluster-level values were assigned to each currently married or cohabiting woman interviewed in that cluster for multilevel modelling (see statistical analysis). Six cluster-level variables were constructed and included in the analysis. Three norm measures are of particular interest because they were derived by aggregating across interviewees in each cluster individual-level survey responses to multiple attitudinal questions. The first is a variable that represents community gender norms on women's participation in decisionmaking. This variable was obtained by aggregating individual-level scores on five attitudinal questions on women's roles in household decision-making. The second is a variable measuring community-level norms about wife beating. This variable was also obtained from responses to five individual-level attitudinal questions on the acceptability of wife battery. The third (last) variable which measures community-level norms about women's sexual rights was created by aggregating individual-level scores on four attitudinal questions related to women refusing sex with their husbands. Responses to these three questions were structured as continuous variables in the multilevel regression model. Higher scores reflect more conservative norms regarding gender roles and that women are more tolerant of domestic violence. The remaining three community-level indicators are the proportion of households in the community which have electricity, proportion of women in the community that have access to media and the percentage of women with secondary education or higher .

Prevalence estimates of physical violence only, sexual violence only, physical or sexual violence were calculated for the total sample by demographics characteristics. Levels of independence (and by implication, level of associations) between demographic characteristics and domestic violence were measured by the chi-square $(\times 2)$ statistic with significance level set at $p=0.05$. Adjusted logistic regression models were estimated for the odds of experiencing IPV in the year preceding the survey at $95 \%$ confidence intervals $(\mathrm{Cl})$. For the logistic regression models, the reference group consists of women with no domestic violence experience in the year preceding the survey and the potential confounders of associations include age, zone of residence, education, wealth, religion and spousal educational level, childhood exposure to domestic violence and the community level variables. All statistical analysis were undertaken using STATA V.I2 that permits assignment of appropriate sample weights based on the complex sampling design of the Nigeria Demographic and Health Survey.

\section{Statistical Analysis}

Because of the considerable overlap between the two types of violence - physical and sexual - they were combined into one binary dependent variable for the regression analysis: 'experienced intimate partner violence in the year before the survey'. A multi-level modeling analysis was used to account for the hierarchical structure of the NDHS data with sampled women clustered within households that are in turn clustered within communities; the communities are themselves clustered within the State. With this structure, the odds of women experiencing physical and/or sexual violence are not independent since women share exposure to common household, community and state-level factors. A multi-level modeling strategy accommodates the hierarchical nature of the data and corrects the estimated standard errors to allow for the clustering of observations within units (Goldstein, et. al., 1998).

Multilevel modeling also provides estimates of the unexplained variance in the dependent variable that is due to unobserved community or state level factors, generally known as the random effect (Bingenheimer and Raudenbush, 2004; Guo and Zhao, 2000). Accordingly, all models include a random intercept to capture heterogeneity among clusters. The models assume that within each cluster, physical and/or sexual violence follows a binomial distribution. Furthermore, it assumes that the cluster means vary according to a normal distribution with a mean (random intercept) and a variance (t2). In other words, they assume that the average in each community differs on the basis of communitycharacteristics. Thus, the models provide a way to account for similarities among individuals residing in the same environment. The variation in random intercepts is captured as the random effect. A significant random effect indicates unexplained heterogeneity between clusters after controlling other factors in the model.

The adaptive quadrature option of the generalized linear latent and mixed models (GLLMM) procedure in STATA was used (Rabe-Hesketh, Skrondal and Pickles, 2004). The adaptive quadrature method works well and improves estimates from samples made up of small clusters (Rabe-Hesketh, Skrondal and Pickles, 2002). All the variables that were significant at the $5 \%$ level in the bivariate analysis were included in the multivariate analysis. Using a stepwise approach, four 3-level 
random intercepts models were fitted. The first unconditional model included no variables and specified only the random intercept (not shown in Table 3, but in Table 4). This model presents the total variance in physical or sexual violence among clusters. The second model adds individual-level predictors and the third model adds household level and attitudinal variables. The final model adds the the community level factors.

The models take a three-level form with women (level I) nested within PSUs (level 2) and nested within states (level 3). The logit of the probability of intimate partner violence can be modeled as follows:

$$
\begin{aligned}
& \quad \operatorname{Logit}(\pi \mathrm{ijk})=\log [\pi \mathrm{ijk} /(I-\pi \mathrm{ijk})]=\beta 0+\beta \text { Ixijk } \\
& +\mu \text { Ijkxijk }+v_{\mathrm{ok}}+\mu_{\mathrm{ojk}}+\varepsilon_{0 \mathrm{ijk}}
\end{aligned}
$$

where $\pi \mathrm{ijk}$ is the dependent variable (intimate partner violence) for the ith woman at level $I$ and jth woman at level 2 and $\mathrm{k}$ indexes at level $3 . \beta 0$ is the intercept, $x i j k$ is an observed value of the independent variable at level $\mathrm{I}, \beta \mathrm{I}$ is its effect, and, $v_{\mathrm{ok}}$ and $\mu$ ojk are the random intercepts for level three and level two respectively, with $\mu \mathrm{ljk}$ being xijk's random effect at level 2. Other parameters of the model include $\mathrm{E}\left[v_{\mathrm{ok}}\right]=\mathrm{E}\left[\mu_{\mathrm{ojk}}\right]=\mathrm{E}\left[\varepsilon_{0 \mathrm{jik}}\right]=0$, $\operatorname{var}\left(v_{\mathrm{ok}}\right)=\sigma^{2}{ }_{\mathrm{v} 0}, \operatorname{var}\left(\mu_{\mathrm{ojk}}\right)=\sigma^{2}{ }_{\mathrm{v} 0}, \operatorname{var}\left(\mu_{\mathrm{ljk}}\right)=\sigma^{2}{ }_{\mu 1}$, $\operatorname{var}\left(\varepsilon_{0 \mathrm{jik}}\right)=\sigma_{\mathrm{e} 0}^{2}$, and $\operatorname{cov}\left(\mu_{\mathrm{ojk},}, \mu_{\mathrm{ljk}}\right)=\sigma_{\mu 01}$. The model assumes that the random effects across different levels and the random effects across different clusters in the samle level are uncorrelated. The GLLAMM program in STATA was used for the multilevel logistic regression models.

\section{Results}

\section{Bivariate analysis}

The second column of Table 2 shows the percentage distribution of the sample by background characteristics while the last three columns show the percentage of the sample sub-groups that reported to experience physical violence, sexual violence, and physical and/or sexual violence in the year preceding the survey. Regarding the composition of the sample by demographic variables, the second column of table 2 shows that: the median age of the women is 30 years; almost all the women (99\%) were younger than their husbands/partners, with close to half (47.5\%) being 10 or more years younger than their husbands/partners; almost half (48.1\%) of the women reported to have no formal education and about a third $(32.8 \%)$ reported to have secondary or higher education; $44.3 \%$ of the women were found in households below the middle (third) wealth quintile and $37 \%$ were found in household above the third wealth quintile; almost two-thirds (63.5\%) resided in the rural areas and two-thirds (66.7\%) were drawn from the three northern regions with the remaining one-third from the three southern regions; $65.4 \%$ of the women were drawn from the four largest ethic groups, Hausa/ Fulani (4I.1\%), Yoruba (13.3\%) and Igbo (II\%); $60.1 \%$ of the women were Moslems and $38.4 \%$ were Christians; alcohol consumption was low among husbands with about $83 \%$ of them reporting to not consume alcohol; childhood exposure to violence is low with about $85 \%$ of the women reporting to have not witnessed family violence; access to information disseminated through the media appeared to be relatively high with two-thirds of the women reporting to have access to the media through which they could obtain information on reproductive health and gender issues; slightly over half (54.2\%) of the women reported to participate in household decision-making, $61.4 \%$ reported to disapprove of spousal violence and $65.9 \%$ reported to approve of sexual rights.

On whether the women experienced domestic violence in the year preceding the survey, the last three columns of table 2 show that $13.4 \%, 4.4 \%$ and $15.2 \%$ of the women reported to experience physical, sexual and physical and/or sexual violence, respectively. That the sum of colums 3 and 4 is greater than column 5 reflects that some women (2.6\%) experienced both physical and sexual violence in the year preceding the survey. The bivariate analysis shows that the percentages of women who reported to experience domestic violence (physical or sexual) in the year preceding the survey vary, in many cases significantly, across the population subgroups defined by the background variables. For instance, women aged 30-39 years, women who were older than their husbands, women who had primary education, urban-based women, women from the South-South, women from southern minorities, Chistian women, women whose husbands were reported to consume alcohol, women who witnessed domestic violence as a child, women who participated in household decision-making, women who accepted domestic violence as part of marriage and those who approved of sexual rights were more likely than at least one of their respective comparison population sub-groups to report physical violence in the year preceding survey. Similarly, women aged 25-29 years, women who were older than their husbands, women who had primary education, ruralbased women, women from the North-east, Chistian women, women whose husbands were reported to consume alcohol, women who had witnessed their mothers being beaten by their father, women who participated in household decision-making, women who accepted domestic violence as part of marriage, 
and those who approved of sexual rights were more likely than at least one of their respective comparison population sub-groups to report sexual violence in the year preceding the 20I3 NDHS. The 'net' effects of these background variables will be estimated at the multivariate analysis level.

\section{Multivariate Analysis}

Table 3 shows the results of a series of multilevel logistic regression analysis that examines the odds of women with certain individual and community level charateristics reporting to experience intimate partner violence in the year preceding the survey. The estimates of the first model show that the odds of experiencing intimate partner violence in the year preceding the survey are significantly associated with a range of demographic and household factors, including the woman's age, spousal age difference, type of marital union, woman's education, number of living children, religion, and region of residence. The results show that while older women were less likely than their younger counterparts to report intimate partner violence, women who were much younger than their husbands were less likely than those who were closer in age to their husbands to report intimate partner violence in the year preceding the survey. Women in monogamous union were less likely than those in polygynous households to report intimate partner violence and an inverted $U$ shaped relationship was found between education and the odds of reporting intimate partner violence in the year preceding the suvey: while women with postsecondary education were significantly less likely than those without formal education to report intimate partner violence, those with primary and secondary education were significantly more likely than those without formal education to report intimate partner violence. Religious affiliation of the women is also shown as an important predictor, with Moslem women significantly less likely than their Christian counterparts to report experiencing intimate partner violence. With respect to ethnicity, lgbo women and women from the northern minorities and southern minorities were significantly more likely than Hausa/Fulani women to report intimate partner violence. Also, the number of living children and the odds of reporting intimate partner violence are positively correlated. The region of residence, exposure to media, type of residence (urban or rural) and level of wealth are insignificantly related to spousal violence.

In model 2, indicators of women's autonomy or participation in household decision-making, permissive social norms around IPV, women's sex rights, childhood exposure to domestic violence among their parents and partner's life styles were aded with a view to determining whether they had independent and incremental effects on the odds of a woman experiencing intimate partner violence in the year preceding the survey. While the indicator of women's participation in household decision making was not significantly associated with the odds of women experiencing IPV, the odds were significantly higher among women who accepted that the husband has the right to beat or hit his spouse and those who believed that women have sexual right. Also, women whose husbands consumed alcohol were significantly more likely than women whose husbands did not consume alcohol to report having experienced IPV. Furthermore, women who witnessed domestic violence between their parents were significantly more likely than those who did not witness violence between their parents to report IPV. Model 2 shows that permissive social norms, beliefs about women's sex rights and partner's life styles have independent and incremental influence on the odds of experiencing IPV in the year preceding the survey.

In model 3, we added the six community-level indicators (estimated at the primary sampling unit) with a view to determining their independent and incremental effects on the odds of a woman experiencing IPV in the year preceding the survey. Of the six community level measures, only two had significant independent and incremental effects on the odds of reporting IPV - the percentage of women in a community who endorse domestic violence and the percentage of women in the community supporting women's sexual rights. The random intercept is significant indicating non-homogeneity across clusters even after micro level individual and community level contextual variables were controlled. While it could be argued that this analysis shows that both individual level and community level characteristics are important predictors of IPV there still remain unobserved individual and community level (contextual) characteristics that might be important to know.

Table 4 shows the random effect variance at the state and primary sampling unit (PSU). The zero models revealed that IPV was clustered at both the PSU and state levels, with more variability between states than within states.

\section{Discussion}

Policy makers, public health and social researchers have recently drawn attention to the violence against women because of its negative consequences on women's health, particularly as a leading cause of preventable morbidity and mortality. Many international agreements, including the United Nations Universal Declaration of Human Rights and 
the Declaration on the Elimination of Violence against Women, have recognized women's fundamental human rights to live free from violence (United Nations, 2006).

The results of this study are in most cases consistent with those of earlier studies in Nigeria (Oyediran and Cunningham, 20I4; Yusuff, et.al., 20I I; Linos, et. al., 20I3) and globally (Krug et al, 2002). Although we do not have additional sources of data to confirm this, we suspect that social norms that condone physical and sexual violence by husbands might have led to some under-reporting of cases of IPV during the 2013 NDHS. Besides, the feelings of shame or embarrassment as well as the stigma associated with discussing marital issues, particularly sex, might have prevented some women from reporting physical/sexual violence experiences. In many Nigerian traditional settings, the beating or hitting of wives or children is permissive as a form of discipline with wife beating considered a means of enforcing conformity with the traditional roles of a woman. In such settings the husband is believed to have the right to punish a woman who refuses to provide sex which is considered one of her major domestic roles. It is, however, important to note that reporting of physical and sexual abuses has improved over time with their occurrences being reported in the media, especially newspapers, on a daily basis.

Some findings are worth further discussion here. For example, the fact that permissive social norms and beliefs about women's sex rights have significant independent and incremental influence on the odds of experiencing IPV in the year preceding the survey draws attention to the need to understand the social norms that tend to promote IPV in different settings with a view to developing appropriate programs to address them. There should be coordinated efforts to educate both men and women on women's sex rights.

The findings that Moslem women were less likely than their Christian counterparts to experience IPV in the year preceding the 2013 NDHS are consistent with those of previous studies in Nigeria (Linos, et. al., 20I3) and Ghana (Tenkorang, et. al.,20I3). It is possible that Moslem women, being less educated than their Christian counterparts, were more likely than their Christian counterparts to be submissive to their partners and consequently avoid engaging in arguments that could lead to physical abuse. With higher levels of education, Christian women are more likely to break the traditional gender rules and embrace life styles that transgress traditional gender roles. It must be emphasized that by itself, no religion embraces violence against women, although some religious scriptures have been quoted out of context to support discriminations against women.
The results of this study could guide programs or activities at different levels by religious leaders to minimize gender-based violence. Appropriate scriptures should be used to reinforce mutual respects between husband and wife. In addition, religious leaders should play significant roles in preventing and mitigating effect of domestic violence. Also noteworthy is the finding that that the odds of being physically or sexually abused are positively associated with the number of living children, even after controlling for other cofound factors. For instance, women who had one or more children were significantly more likely than women with no child to experience IPV in the year before the 2013 NDHS. As hypothesized in previous studies with similar findings (Diaz-Olavarrieta et. al., 2002; Akmatov, et. al., 2008), the financial pressure imposed upon fathers by increased number of children may put a significant burden on families and explode into violence.

Intimate partner violence remains an important human rights and public health problems in Nigeria and elsewhere. The interventions to address it requires the involvement of many actors working together at the community, state and national levels. At each level, interventions must include empowering women and girls to have greater voice, reaching out to men with appropriate messages on spousal communication and equity, providing for the needs of victims and increasing sanctions against perpetrators of domestic violence.. Reducing domestic violence requires commitment to changing community and societal norms that promote wife beating and forced sex. The new values must be communicated to children before they get married.

To counter the traditional values that directly or indirectly endorse IPV, community level interventions that involve dialogue between men and women and are human-rights based, should be put in place. Such interventions should involve use of targeted, enabling and catalytic approaches in programming for social change. Efforts should be made to emphasize the individual and community-level consequences of physical and sexual violence - physical and sexual violence not only affect the individuals but impact on community well-being and stability. The spatial variations in the level of domestic violence indicate that some States have more work to do than the others in minimizing domestic violence. At the community/State level, efforts should be made to understand the contextual factors that facilitate domestic violence and develop programs to address them. Donors, activists, community and religious leaders should work with the State government policy makers to develop appropriate programs to 
address contextual factors that influence domestic violence.

Due to the cross-sectional nature of the study data, it has been difficult to establish the causal relationships between covariates and the outcomes of interest. We recognize that domestic violence as an outcome is more appropriately addressed with qualitative data; being a normative measure, it is difficult to express quantitatively. There is, therefore, a need for further qualitative research to gain an indepth understanding of the factors underlying domestic violence in different parts of Nigeria. Despite the data limitations, this study provides valuable information that could inform program interventions to address domestic violence by policy makers and activists. For instance, both policymakers and activists in this field should give priority to creating a social environment that allows and promotes equitable and non-violent spousal relationships. Also, cultural and community norms and values that promote mutual respects between husbands and wife should be promoted.

\section{References}

Akmatov MK, Mikolajczyk RT, Labeb S, Dhaher E, Khann MM: Factors associated with wife beating in Egypt: Analysis of two surveys (1995 and 2005). BMC Women's Health. 2008, 8: I5I0.1 I86/I472-6874-8-I5.

http://www.biomedcentral.com//472-6874/8/I5,

Antai D. Controlling behavior, power relations within intimate relationships and intimate partner physical and sexual violence against women in Nigeria. BMC Public Health. 20 I I; I (I):5 I I.

Antai D and Adaji S.Community-level influences on women's experience of intimate partner violence and terminated pregnancy in Nigeria: a multilevel analysis. BMC Pregnancy Childbirth. 2012 Nov |4; | 2: I 28. doi: 10.1 |86/|47|-2393-I2-I 28.

Bensley L, Van Eenwyk J, Wynkoop Simmons K. Childhood family violence history and women's risk for intimate partner violence and poor health. American Journal of Preventive Medicine 2003 Jul;25(I):38-44.

Bingenheimer JB and Raudenbush SW, Statistical and substantive inferences in public health: issues in the application of multilevel models, Annual Review of Public Health, 2004, 25:53-77.

Boyle MH, Georgiades K, Cullen J, Racine Y. Community influences on intimate partner violence in India: Women's education, attitudes towards mistreatment and standards of living. Social Science and Medicine, 2009 Sep;69(5):69I7. doi: 10.1016/j.socscimed.2009.06.039. Epub 2009 Jul I
Coker AL, Richter DL. Violence against women in Sierra Leone: frequency and correlates of intimate partner violence and forced sexual intercourse. African Journal of Reproductive Health 1998;2:6172.

Decker, M.R., G.R.I. Seage, D. Hemenway, A. Raj, N. Saggurti, D. Balaiah, and J.G. Silverman. 2009. "Intimate Partner Violence Functions as Both a Risk Marker and Risk Factor for Women's HIV Infection: Findings from Indian Husband-Wife Dyads." JAIDS Journal of Acquired Immune Deficiency Syndromes 5I (5): 593-600.

Diaz-Olavarrieta C, Ellertson C, Paz F, de Leon SP, Alarcon-Segovia D: Prevalence of battering among 1780 outpatients at an internal medicine institution in Mexico. Soc Sci Med. 2002, 55 (9): 1589-I602. 10.1016/S0277-9536(0I)00293-3.

Ellsberg MC, Rena R, Herrera A, Liljestrand J, Winkvist A. Wife abuse among women of childbearing age in Nicaragua. American Journal of Public Health 1999;89:24I-4.

Emenike, E., S. Lawoko, K. Dalal. 2008. Intimate partner violence and reproductive health of women in Kenya. International Nursing Review 55(I):97- 102

Finkler, Kaja "Gender, Domestic Violence and Sickness in Mexico." Social Science Medicine. 1997; 45(8): I|47-I I60.

Gilchrist E, Johnson R, Takriti R, Weston S, Beech A, Kebbell M: Domestic violence offenders: characteristics and offending related needs. Findings 217. 2003, London: Home office. Research, development, and statistics directorate, http://www.homeoffice.gov.uk/rds/pdfs2/r2 I 7.pdf

Goldstein, H., J. Rashbash, I. Plewis, D. Draper, L. Browne, M.Yang, G.Woodhouse, and M Healy. A User's Guide to MLwin. London:Institute of Education, 1998.

Guo $\mathrm{G}$ and Zhao H, Multilevel modeling for binary data, Annual Review of Sociology, 2000, 26: 44I462

Heise L, Pitanguy J, Germain A. Violence against women: The hidden health burden. Washington, DC: World Bank; 1994. (Discussion Paper No. 255).

Heise, L. (1998). "Violence against women: an integrated, ecological framework." Violence Against Women 4 (3): 262-290

Heise, Lori L; (20I2) Determinants of partner violence in low and middle-income countries : exploring variation in individual and populationlevel risk. PhD thesis, London School of Hygiene \& Tropical Medicine.

Hindin, M.J. and L.S. Adair. 2002. Who's at risk? Factors associated with intimate partner violence 
in the Philippines. Social Science and Medicine 55(8): I 385-99

Hindin, Michelle J., Sunita Kishor, and Donna L. Ansara. 2008. Intimate Partner Violence among Couples in 10 DHS Countries: Predictors and Health Outcomes. DHS Analytical Studies No. 18. Calverton, Maryland, USA: Macro International Inc.

Hoffman K, Demo DH, Edwards JN. Physical wife abuse in a non-Western society: an integrated theoretical approach. Journal of Marriage and the Family 1994;56: | 31-46.

Karoline Fonck, K., Els, L., Kidula, N., NdinyaAchola, J and Temmerman, M. (2005) "Increased Risk of HIV in Women Experiencing Physical Partner Violence in Nairobi, Kenya" AIDS and Behavior, 9 (3): 335-339 September 2005

Kiragu, Jane "Policy Review: HIV Prevention and Women's Rights: Working for One Means Working for Both." AIDS Captions. 1995; 2(3): 40-46.

Koenig MA, Stephenson R, Ahmed S, Jejeebhoy SJ, Campbell J. Individual and contextual determinants of domestic violence in north India. Am J Public Health. 2006;96(I): I 32--- I 38.

Krug EG et al., eds. World report on violence and health. Geneva, World Health Organization, 2002

Linos, N., Slopen, N., Subramanian, SV., Berkman, L. and Kawachi, I. (20I3): Influence of community social norms on spousal violence: A populationBased Multilevel Study of Nigerian Women. American Journal of Public Health, 103(I): 148155

MacQuarrie, Kerry L.D., Rebecca Winter, and Sunita Kishor. 20I3. Spousal Violence and HIV: Exploring the Linkages in Five Sub-Saharan African Countries. DHS Analytical Studies No. 36. Calverton, Maryland, USA: ICF International.

Makayoto LA, Omolo J, Kamweya AM, Harder VS, Mutai J. "Prevalence and associated factors of intimate partner violence among pregnant women attending Kisumu District Hospital, Kenya." Maternal Child Health Journal, 2013 Apr; I7(3):44I-7. doi: 10.1007/s 10995-0I2-I0I5$x$.

Martin SL, Tsui AO, Maitra K, Marinshaw R. Domestic violence in Northern India. American Journal of Epidemiology 1999; I50:4I 7-26.

Martin SL, Moracco KE, Garro J, Tsui AO, Kupper $\mathrm{LL}$, Chase JL, et al. Domestic violence across generations: findings from northern India. International Journal of Epidemiology 2002;31:560-72.

Michau L. Approaching old problems in new ways: community mobilization as a primary prevention strategy to combat violence against women. Gend ,and Development 2007; 15 (I):95--- 09.

National Population Commission (NPC) [Nigeria] and ICF Macro. 2009. Nigeria Demographic and Health Survey 2008. Abuja, Nigeria: National Population Commission and ICF Macro

National Population Commission (NPC) [Nigeria] and ICF International. 20I4. Nigeria Demographic and Health Survey 2013. Abuja, Nigeria, and Rockville, Maryland, USA: NPC and ICF International.

Odimegwu, Clifford O. "Couple formation and domestic violence among the Tiv of Benue State, Nigeria." Paper presented at the International Colloquium Gender, Population and Development in Africa organized by UAPS, INED, ENSEA, IFORD, Abidjan I6-2I July 200I.

Odujinrin, $O$. "Wife battering in Nigeria." International Journal of Gynaecology and Obstetrics. 1993; 4I(2): I59-64.

Okemgbo, CN; Omideyi, AK; and Odimegwu, CO. "Prevalence, patterns and correlates of domestic violence in selected lgbo communities of Imo State, Nigeria." African Journal of Reproductive Health. 2002; 6(2): I0I-II4.

Ondicho, T. G. "Battered Women: A socio-legal perspective of their experiences in Nairobi." Africa Study Monographs, 2000; 2 I (I): 35-44.

Ononokpono DN, and Azfredrick EC. (2014): Intimate partner violence and the utilization of maternal health care services in Nigeria. Health Care Women Int. 35(7-9):973-89. doi: 10.1080/07399332.2014.924939. Epub 20I4 Aug 8.

Oyediran, Kola' and Isiugo-Abanihe, UC. (2005). "Perceptions of Nigerian Women on Domestic Violence: Evidence from 2003 Nigeria Demographic and Health Survey, African Journal of Reproductive Health, 9(2): 38-53

Oyediran, K., \& Cunningham, M. (20/4). Spatial patterns in domestic violence and HIV prevalence in Nigeria. Journal of Therapy and Management in HIV Infection, 2, 16-23. http://doi.org/I0.I2970/2309-0529.20I4.02.0I.3

Plichta SB Intimate partner violence and physical health consequences: policy and practice implications. J Interpers Violence. 2004 Nov; I (I I): I 296-323.

Rabe-Hesketh S, Skrondal A and Pickles A, Reliable estimation of generalized linear mixed models using adaptive quadrature, Stata Journal, 2002, 2(I): I-2I.

Rabe-Hesketh S, Skrondal A and Pickles A,GLLAMMManual,U.C. BerkeleyDivision of BiostatisticsWorking Paper Series, Berkeley, 
CA,USA: University of California, Berkeley, 2004, No. 160.

Sarkar NN The impact of intimate partner violence on women's reproductive health and pregnancy outcome. J Obstet Gynaecol. 2008 Apr;28(3):2667I. doi: 10.1080/0I4436I08020424I5.

Schuler SR, Hashemi SM, Riley AP, Akhter S. Credit programs, patriarchy and men's violence against women in rural Bangladesh. Social Science and Medicine 1996;43: I 729-42.

Silverman, J.G., J. Gupta, M.R. Decker, N. Kapur, and A. Raj. 2007. Intimate partner violence and unwanted pregnancy, miscarriage, induced abortion, and stillbirth among a national sample of Bangladeshi women. BJOG: An International Journal of Obstetrics and Gynaecology I | 4(10): 1246-52

Solanke, BL Association between intimate partner violence and utilisation of maternal health services in Nigeria 28 (2): 933-945, No 2, July 2014: Supplement on Demographic and Health Surveys in Africa; Guest Editor: Antony Chikutsa

Tenkorang, E. Y., Yeboah, E. H., Owusu, Y. A., \& Bannerman, R. (20/3). Factors influencing domestic and marital violence against women in Ghana. Journal of Family Violence, 28(8), 77I781.

United Nations General Assembly. In-depth study on all forms of violence against women. New York, United Nations, 2006.

Usdin S, Scheepers E, Goldstein S, Japhet G. Achieving social change on gender-based violence: a report on the impact evaluation of Soul City's fourth series. Soc Sci Med. 2005;6I(I I):2434--2445.

van der Straten A, King R, Grinstead O, Vittinghoff E, Serufilira A, Allen S. Sexual coercion, physical violence, and HIV infection among women in steady relationships in Kigali, Rwanda. AIDS and Behavior 1998;2:6I-73.

Vyas, S. and Watts, C. (2009), How does economic empowerment affect women's risk of intimate partner violence in low and middle income countries? A systematic review of published evidence. J. Int. Dev., 21: 577-602. doi: I0.1002/jid. 1500

Watts C, Keough E, Ndlovu M, Kwaramba R. Withholding of sex and forced sex: dimensions of violence against Zimbabwean women. Reproductive Health Matters 1998;6:57-65.

World Health Organization. Violence against women: Legislation. Geneva: WHO; 2000:5.

Yusuf $\mathrm{OB}$, Arulogun $\mathrm{OS}$, Oladepo $\mathrm{O}$ and Olowokeere F (20II): Physical violence among intimate partners in Nigeria: Amulti level analysis, Journal of Public Health and Epidemiology Vol. 3(5): 240-247 Available online at http://www.academicjournals.org/jphe ISSN 214I 2316 (C) 20I I Academic Journals

Table I Individual, household and community variables used in modeling marital violence in Nigeria

\begin{tabular}{|c|c|}
\hline Variables & Operational definition and measurement \\
\hline \multicolumn{2}{|l|}{ Outcome variable } \\
\hline Intimate Partner Violence & $\begin{array}{l}\text { - Created from a 'yes/no' response to each of nine questions on acts that } \\
\text { suggest exposure to intimate partner violence. A 'yes' response indicates } \\
\text { that the act took place in the year preceding the survey and a 'no' } \\
\text { response indicates that the act did not take place in the year preceding } \\
\text { the survey. From the dichotomous 'yes/no' responses, an index } \\
\text { representing exposure to intimate partner violence (physical or sexual) } \\
\text { in the year preceding the survey respondents was created, with scores } \\
\text { ranging from 0-9. Women who scored } 0 \text { were then classified as not } \\
\text { experiencing intimate partner violence during the year preceding the } \\
\text { survey while those who scored I or more were classified as having } \\
\text { experienced intimate partner violence in the year preceding survey. }\end{array}$ \\
\hline \multicolumn{2}{|l|}{ Individual and household variables } \\
\hline Age & $\begin{array}{l}\text { - Self-reported age of respondent at the time of the survey, grouped into } \\
\text { below } 20 \text { years; } 20-24 \text { years; } 25-29 \text { years; } 30-39 \text { years and } 40 \text { years and } \\
\text { above }\end{array}$ \\
\hline Type of marital union & $\begin{array}{l}\text { - Defined by the number of wives the husband had at the time of the } \\
\text { survey: (Monogamous, if only one and polygamous if two or more) }\end{array}$ \\
\hline Age difference with partner/spouse & $\begin{array}{l}\text { The absolute difference between the self-reported age of respondent } \\
\text { and the given age of the husband/partner recoded as: I = Wife older } \\
\text { than husband; } 2=\text { husband older by } 0-4 \text { years; } 3=\text { husband older by } 5-9 \\
\text { years; } 4=\text { husband older by } 10-14 \text { years; and } 5=\text { husband older by } 15 \\
\text { or more years }\end{array}$ \\
\hline
\end{tabular}




\begin{tabular}{|c|c|}
\hline Parity & - Number of living children grouped as: $0 ; 1-2 ; 3-4$ and 5 or more \\
\hline Education & - Highest Level of Education attained: None; Primary; Secondary; Higher \\
\hline Religious affiliation & $\begin{array}{l}\text { - Self-reported Religious Group to which the woman is affiliated: } \\
\text { Christians, Muslim, Traditionalist and no religion }\end{array}$ \\
\hline Place of residence & - Current Place of Residence: Urban; Rural \\
\hline Region & $\begin{array}{l}\text { - The geo-political zone of the country in which the the respondent was } \\
\text { living at the time of interview: North central; North-east; North-west; } \\
\text { South-east; South-south; South-west }\end{array}$ \\
\hline Media access & $\begin{array}{l}\text { - A composite variable derived from the frequency of access to } \\
\text { newspaper/magazine, radio and television ( } \mathrm{Yes}, \mathrm{No})\end{array}$ \\
\hline Household wealth index & $\begin{array}{l}\text { - A composite index of household possessions, assets and amenities } \\
\text { broken into five equal parts and labeled as: Poorest; poorer; middle; } \\
\text { richer and richest }\end{array}$ \\
\hline $\begin{array}{l}\text { Women participation in household } \\
\text { decision making }\end{array}$ & $\begin{array}{l}\text { - A composite variable reflecting woman's participation in household } \\
\text { decision making on health care, large household purchases, daily } \\
\text { household purchases and mobility (visiting families and relatives): Yes = } \\
\text { involved in decision making; No = not participating in decision making }\end{array}$ \\
\hline Attitudes toward spousal violence & $\begin{array}{l}\text { - A composite variable reflecting woman's attitudes toward wife-beating } \\
\text { for the following reasons: wife goes out without telling her husband; wife } \\
\text { neglects the children; wife argues with husband; wife refuses to have sex } \\
\text { with spouse and wife urns the food - it is a measure of acceptance of } \\
\text { marital violence as a norm = accepts; does not accept }\end{array}$ \\
\hline $\begin{array}{l}\text { Childhood exposure to marital } \\
\text { violence }\end{array}$ & $\begin{array}{l}\text { - Self reported history of childhood exposure to family marital violence } \\
\text { (Father previously abused the mother of respondent in her presence; } \\
\text { Father never abused her mother) }\end{array}$ \\
\hline Ethnic affiliation & $\begin{array}{l}\text { - Self-reported ethnic affiliation of respondent at the time of the survey, } \\
\text { grouped into Hausa/Fulani, Igbo, Yoruba, Northern minority, Southern } \\
\text { minority and others }\end{array}$ \\
\hline Husband drink alcohol & $\begin{array}{l}\text { - Respondent's report of partner's alcohol comsuption: measured as yes if } \\
\text { husnad was reported to consume alcohol and No if husband was } \\
\text { reported to not consume alcohol }\end{array}$ \\
\hline Women's sexual right & $\begin{array}{l}\text { - A composite score of a woman's right to not have sex with her husband } \\
\text { measured from responses to questions related to refusing sex when not } \\
\text { wanted, or asking husband to use condom. The score ranges between } 0 \\
\text { and 2; coded as yes or no }\end{array}$ \\
\hline \multicolumn{2}{|l|}{ Community level variables } \\
\hline $\begin{array}{l}\text { Community level of female with at } \\
\text { least } \\
\text { secondary education attainment }\end{array}$ & $\begin{array}{l}\text { - Proportion of Women in the community with at least secondary school } \\
\text { education }\end{array}$ \\
\hline Acceptance of marital violence & - Percent of women in the community endorsing marital violence \\
\hline $\begin{array}{l}\text { Community norms about women } \\
\text { decision making power }\end{array}$ & $\begin{array}{l}\text { - Mean PSU-level factor score for women's participation in decision- } \\
\text { making based on whether the women make final decision on the } \\
\text { following: Own health care; large household purchase, household } \\
\text { purchase for daily needs; visit to relative; how to spend money, what to } \\
\text { do with husband's earnings }\end{array}$ \\
\hline $\begin{array}{l}\text { Community norms about women's } \\
\text { sexual rights }\end{array}$ & $\begin{array}{l}\text { - Mean PSU-level factor score for women's right to not have sex with } \\
\text { husband based on: not having sex when husband has STD; husband has } \\
\text { other women; tired or not in mood; ask husband to use condom if he } \\
\text { has STD }\end{array}$ \\
\hline Access to media & - Percent of women in the community that have access to media. \\
\hline Household with electricity & - Proportion of household in the primary sample unit with electricity \\
\hline
\end{tabular}


Table 2. Percentage distribution of respondents by background characteristics, and, the percentage of women in each sub-population group who reported to experience intimate partner violence in the year preceding the survey: 20I3 NDHS

\begin{tabular}{|c|c|c|c|c|}
\hline \multirow[t]{2}{*}{ Characteristics } & \multirow{2}{*}{$\begin{array}{c}\text { Selected } \\
\text { Characteristics }\end{array}$} & \multicolumn{3}{|c|}{ Forms of Intimate Partner Violence } \\
\hline & & Physical & Sexual & IPV \\
\hline Number of Cases & 19,924 & 2,674 & 885 & 3,019 \\
\hline Percent & 100.00 & 13.4 & 4.4 & 15.2 \\
\hline $\begin{array}{l}\text { Age: } \\
\text { Below } 20 \text { years } \\
20-24 \text { years } \\
25-29 \text { years } \\
30-39 \text { years } \\
40 \text { years and above } \\
\text { (Median) }\end{array}$ & $\begin{array}{r}8.0 \\
15.8 \\
20.9 \\
32.6 \\
22.6 \\
(30.0)\end{array}$ & $\begin{array}{r}7.1 \\
12.1 \\
13.6 \\
15.3 \\
13.8\end{array}$ & $\begin{array}{l}4.1 \\
4.8 \\
5.0 \\
4.4 \\
3.8\end{array}$ & $\begin{array}{r}9.6 \\
14.4 \\
15.4 \\
16.7 \\
15.2\end{array}$ \\
\hline $\begin{array}{l}\text { Spousal age difference: } \\
<0 \text { years (Respondent older than husband/partner) } \\
0-4 \text { years } \\
5-9 \text { years } \\
10-14 \text { years } \\
15 \text { years and above }\end{array}$ & $\begin{array}{r}1.0 \\
17.5 \\
34.1 \\
23.8 \\
23.7\end{array}$ & $\begin{array}{l}25.9 \\
16.7 \\
14.7 \\
12.1 \\
10.0\end{array}$ & $\begin{array}{r}10.9 \\
4.5 \\
4.5 \\
4.3 \\
4.2\end{array}$ & $\begin{array}{l}29.1 \\
18.4 \\
16.2 \\
13.9 \\
12.0\end{array}$ \\
\hline $\begin{array}{l}\text { Highest level of education: } \\
\text { None } \\
\text { Primary } \\
\text { Secondary } \\
\text { Post-secondary }\end{array}$ & $\begin{array}{r}48.1 \\
19.1 \\
25.4 \\
7.4\end{array}$ & $\begin{array}{r}7.1 \\
22.4 \\
19.9 \\
9.9\end{array}$ & $\begin{array}{l}3.8 \\
6.1 \\
4.9 \\
2.6\end{array}$ & $\begin{array}{r}9.0 \\
23.8 \\
21.4 \\
11.6\end{array}$ \\
\hline $\begin{array}{l}\text { Wealth Quintile: } \\
\text { First } \\
\text { Second } \\
\text { Third } \\
\text { Fourth } \\
\text { Fifth }\end{array}$ & $\begin{array}{l}22.9 \\
21.4 \\
17.9 \\
18.3 \\
19.6\end{array}$ & $\begin{array}{r}7.6 \\
13.1 \\
16.4 \\
16.3 \\
15.2\end{array}$ & $\begin{array}{l}4.2 \\
5.6 \\
6.1 \\
3.3 \\
3.0\end{array}$ & $\begin{array}{r}9.5 \\
15.0 \\
18.8 \\
17.4 \\
16.6\end{array}$ \\
\hline $\begin{array}{l}\text { Place of residence: } \\
\text { Urban } \\
\text { Rural }\end{array}$ & $\begin{array}{l}36.5 \\
63.5\end{array}$ & $\begin{array}{l}15.3 \\
12.3\end{array}$ & $\begin{array}{l}3.6 \\
4.9 \\
\end{array}$ & $\begin{array}{l}16.7 \\
14.3\end{array}$ \\
\hline $\begin{array}{l}\text { Region: } \\
\text { North-central } \\
\text { North-east } \\
\text { North-west } \\
\text { South-east } \\
\text { South-south } \\
\text { South-west }\end{array}$ & $\begin{array}{r}13.8 \\
16.5 \\
36.4 \\
8.4 \\
9.8 \\
15.1\end{array}$ & $\begin{array}{r}18.6 \\
13.4 \\
4.6 \\
17.9 \\
26.3 \\
19.1\end{array}$ & $\begin{array}{r}5.4 \\
12.0 \\
1.3 \\
5.4 \\
5.5 \\
1.6\end{array}$ & $\begin{array}{r}19.6 \\
19.7 \\
5.6 \\
18.7 \\
27.2 \\
19.5\end{array}$ \\
\hline $\begin{array}{l}\text { Ethnic affiliation: } \\
\text { Hausa/Fulani } \\
\text { lgbo } \\
\text { Yourba } \\
\text { Northern minorities } \\
\text { Southern minorities } \\
\text { Others including foreigners }\end{array}$ & \begin{tabular}{r|}
41.1 \\
11.0 \\
13.3 \\
24.1 \\
9.5 \\
1.0
\end{tabular} & $\begin{array}{r}3.9 \\
18.5 \\
17.7 \\
19.5 \\
26.1 \\
25.0\end{array}$ & \begin{tabular}{r|}
2.7 \\
5.2 \\
1.5 \\
8.5 \\
4.6 \\
11.0
\end{tabular} & $\begin{array}{r}5.6 \\
19.6 \\
18.0 \\
22.8 \\
26.6 \\
27.8\end{array}$ \\
\hline $\begin{array}{l}\text { Religious affiliation: } \\
\text { Christians } \\
\text { Muslim } \\
\text { Others }\end{array}$ & $\begin{array}{r}38.4 \\
60.1 \\
1.6 \\
\end{array}$ & $\begin{array}{r}24.0 \\
6.4 \\
23.4\end{array}$ & $\begin{array}{l}6.1 \\
3.4 \\
4.6\end{array}$ & $\begin{array}{r}25.4 \\
8.4 \\
24.2\end{array}$ \\
\hline $\begin{array}{l}\text { Husband consumes alcohol? } \\
\text { Yes } \\
\text { No }\end{array}$ & $\begin{array}{l}17.3 \\
82.7\end{array}$ & $\begin{array}{r}35.1 \\
8.9\end{array}$ & $\begin{array}{l}8.9 \\
3.5\end{array}$ & $\begin{array}{l}36.7 \\
10.6\end{array}$ \\
\hline $\begin{array}{l}\text { Childhood exposure to violence: Father ever beat her mother? } \\
\text { Yes } \\
\text { No } \\
\text { Don't Know }\end{array}$ & $\begin{array}{r}8.1 \\
84.8 \\
7.1 \\
\end{array}$ & $\begin{array}{l}35.7 \\
10.9 \\
18.4\end{array}$ & $\begin{array}{r}12.6 \\
3.7 \\
4.5 \\
\end{array}$ & $\begin{array}{l}38.3 \\
12.5 \\
20.4\end{array}$ \\
\hline Access to media? & & & & \\
\hline
\end{tabular}




\begin{tabular}{|l|r|r|r|r|}
\hline Yes & 67.9 & 14.7 & 4.4 & 16.4 \\
No & 32.1 & 10.7 & 4.5 & 12.5 \\
\hline Woman participates in household decision making? & & & & \\
Yes & 54.2 & 18.4 & 5.0 & 20.1 \\
No & 45.8 & 7.6 & 3.8 & 9.3 \\
\hline Attitudes toward spousal violence & & & & \\
Accept violence & 38.6 & 16.4 & 7.0 & 19.1 \\
Does not accept violence & 61.4 & 11.6 & 2.8 & 12.7 \\
\hline Attitudes toward sexual right: & & & & \\
Accepts sexual right & 65.9 & 16.3 & 5.1 & 18.1 \\
Does not believe in sexual right & 34.1 & 7.9 & 3.1 & 9.4 \\
\hline
\end{tabular}

Table 3: Multilevel odds ratios assessing effects of individual and community characteristics on marital violence (physical or sexual) among Nigerian married/cohabiting women, 2013 NDHS

\begin{tabular}{|c|c|c|c|}
\hline Characteristics & Model I & Model 2 & Model 3 \\
\hline & Odds ratio (SE) & Odds ratio (SE) & $\begin{array}{r}\text { Odds ratio } \\
\text { (SE) }\end{array}$ \\
\hline Intercept & $.283 * *(.115)$ & $.130 * * *(.05 \mathrm{I})$ & $.052 * * *(.025)$ \\
\hline Age & $.985 * * *(.004)$ & $.986 * * *(.004)$ & $.985 * * *(.004)$ \\
\hline $\begin{array}{l}\text { Spousal age difference: } \\
<0 \text { years (Respondent older than husband/partner) } \\
0-4 \text { years } \\
5-9 \text { years } \\
10-14 \text { years } \\
15 \text { years and above }\end{array}$ & $\begin{array}{r}1.000 \\
.528 * * *(.121) \\
.528 * * *(.122) \\
.508 * * *(.113) \\
.422 * * *(.094)\end{array}$ & $\begin{array}{r}1.000 \\
.577 *(.139) \\
.557 *(.140) \\
.547 * *(.130) \\
.447 * * *(.103)\end{array}$ & $\begin{array}{r}1.000 \\
.637 *(.151) \\
.671(.152) \\
.585 *(.132) \\
.496 * * *(.107)\end{array}$ \\
\hline $\begin{array}{l}\text { Type of union: } \\
\text { Monogamous } \\
\text { Polygamous (ref) }\end{array}$ & $\begin{array}{r}.670 * * *(.04 I) \\
1.000 \\
\end{array}$ & $\begin{array}{r}.710 * * *(.041) \\
1.000 \\
\end{array}$ & $\begin{array}{r}.720 * * *(.036) \\
1.000 \\
\end{array}$ \\
\hline $\begin{array}{l}\text { Highest level of education: } \\
\text { None } \\
\text { Primary } \\
\text { Secondary } \\
\text { Post-secondary }\end{array}$ & $\begin{array}{r}1.000 \\
1.412 * * *(.162) \\
1.22 \mid(.146) \\
.621 * * *(.084) \\
\end{array}$ & $\begin{array}{r}1.000 \\
1.360 * *(.151) \\
1.230(.156) \\
.656 *(.096) \\
\end{array}$ & $\begin{array}{r}1.000 \\
1.091(.149) \\
1.032(.118) \\
.621 * * *(.080) \\
\end{array}$ \\
\hline $\begin{array}{l}\text { Wealth Quintile: } \\
\text { First } \\
\text { Second } \\
\text { Third } \\
\text { Fourth } \\
\text { Fifth }\end{array}$ & $\begin{array}{r}1.000 \\
.876(.090) \\
.902(.108) \\
.834(.094) \\
.745(.122) \\
\end{array}$ & $\begin{array}{r}1.000 \\
.883(.092) \\
.883(.111) \\
.792 *(.093) \\
.720 *(.124) \\
\end{array}$ & $\begin{array}{r}1.000 \\
.974(.120) \\
.968(.132) \\
.945(.139) \\
.756(.126) \\
\end{array}$ \\
\hline $\begin{array}{l}\text { Place of residence: } \\
\text { Urban } \\
\text { Rural }\end{array}$ & $\begin{array}{r}1.234(.151) \\
1.000\end{array}$ & $\begin{array}{r}1.224(.149) \\
1.000\end{array}$ & $\begin{array}{r}1.192(.149) \\
1.000\end{array}$ \\
\hline $\begin{array}{l}\text { Number of living children: } \\
0 \text { No child } \\
\text { I }-2 \text { children } \\
3-4 \text { children } \\
5 \text { children and above }\end{array}$ & $\begin{array}{r}\mathrm{I} .000 \\
\mathrm{I} .473 * * *(.158) \\
\mathrm{I} .823 * * *(.258) \\
\mathrm{I} .990 * * *(.294)\end{array}$ & $\begin{array}{r}\mathrm{I} .000 \\
\mathrm{I} .43 \mathrm{|} * * *(.149) \\
\mathrm{I} .756(.239) \\
\mathrm{I} .839 * * *(.265)\end{array}$ & $\begin{array}{r}1.000 \\
1.478 * * *(.156) \\
1.850 * * *(.24 I) \\
1.936 * * *(.281)\end{array}$ \\
\hline $\begin{array}{l}\text { Religious affiliation } \\
\text { Christians } \\
\text { Muslim } \\
\text { Others } \\
\end{array}$ & $\begin{array}{r}1.000 \\
.595 * * *(.072) \\
1.291(.233) \\
\end{array}$ & $\begin{array}{r}1.000 \\
.789 * *(.064) \\
1.343(.287) \\
\end{array}$ & $\begin{array}{r}1.000 \\
.806 * *(.059) \\
1.268(.279) \\
\end{array}$ \\
\hline $\begin{array}{l}\text { Region: } \\
\text { North-central } \\
\text { North-east } \\
\text { North-west } \\
\text { South-east } \\
\text { South-south } \\
\text { South-west }\end{array}$ & $\begin{array}{r}1.000 \\
1.913(.934) \\
.433(.204) \\
1.053(.459) \\
1.590(.666) \\
1.288(.460) \\
\end{array}$ & $\begin{array}{r}1.000 \\
1.940(.780) \\
.469 *(.188) \\
.816(.325) \\
1.105(.441) \\
1.244(.388) \\
\end{array}$ & $\begin{array}{r}1.000 \\
1.715(.631) \\
.582(.215) \\
.661(.203) \\
1.043(.364) \\
1.118(.319) \\
\end{array}$ \\
\hline $\begin{array}{l}\text { Ethnic affiliation: } \\
\text { Hausa/Fulani }\end{array}$ & 1.000 & 1.000 & 1.000 \\
\hline
\end{tabular}




\begin{tabular}{|c|c|c|c|}
\hline $\begin{array}{l}\text { Igbo } \\
\text { Yourba } \\
\text { Northern minorities } \\
\text { Southern minorities } \\
\text { Others including foreigners }\end{array}$ & $\begin{array}{r}.495 * *(.279) \\
1.445(.321) \\
1.685^{* * *}(.260) \\
1.780 * * *(.256) \\
2.193 * * *(.424) \\
\end{array}$ & $\begin{array}{r}1.233(.261) \\
1.354(.312) \\
1.482 * *(.198) \\
1.617^{* *}(.270) \\
1.928 * * *(.399) \\
\end{array}$ & $\begin{array}{r}\mathrm{I} .285(.28 \mathrm{I}) \\
\mathrm{I} .420(.373) \\
\mathrm{I} .434 * *(.207) \\
\mathrm{I} .430(.275) \\
\mathrm{I} .79 \mathrm{I} * * *(.322)\end{array}$ \\
\hline $\begin{array}{l}\text { Access to media? } \\
\text { Yes } \\
\text { No }\end{array}$ & $\begin{array}{r}1.056(.132) \\
1.000 \\
\end{array}$ & $\begin{array}{r}1.118(.143) \\
1.000 \\
\end{array}$ & $\begin{array}{r}1.097(.134) \\
1.000 \\
\end{array}$ \\
\hline $\begin{array}{l}\text { Woman participates in household decision making? } \\
\text { Yes } \\
\text { No }\end{array}$ & & $\begin{array}{r}1.068(.174) \\
1.000 \\
\end{array}$ & $\begin{array}{r}1.061(.145) \\
1.000 \\
\end{array}$ \\
\hline $\begin{array}{l}\text { Attitudes toward spousal violence: } \\
\text { Accepts violence } \\
\text { Does not accept violence }\end{array}$ & & $\begin{array}{r}1.427 * * *(.117) \\
1.000 \\
\end{array}$ & $\begin{array}{r}1.342 * * *(.105) \\
1.000 \\
\end{array}$ \\
\hline $\begin{array}{l}\text { Attitudes toward sexual right: } \\
\text { Accepts sexual right } \\
\text { Does not believe in sexual right }\end{array}$ & & $\begin{array}{r}1.242 * *(.091) \\
1.000 \\
\end{array}$ & $\begin{array}{r}1.115(.086) \\
1.000 \\
\end{array}$ \\
\hline $\begin{array}{l}\text { Husband consumes alcohol? } \\
\text { Yes } \\
\text { No }\end{array}$ & & $\begin{array}{r}2.779 * * *(.298) \\
1.000 \\
\end{array}$ & $\begin{array}{r}2.708 * * *(.290) \\
1.000 \\
\end{array}$ \\
\hline $\begin{array}{l}\text { Childhood exposure to violence? } \\
\text { Yes } \\
\text { No } \\
\text { Don't Know }\end{array}$ & & $\begin{array}{r}2.009 * * *(.217) \\
1.000 \\
1.566 * * *(.201) \\
\end{array}$ & $\begin{array}{r}2.029 * * *(.213) \\
1.000 \\
1.455 * * *(.172) \\
\end{array}$ \\
\hline $\begin{array}{l}\% \text { of Women in the community (psu) with at least secondary } \\
\text { education }\end{array}$ & & & $1.133(.254)$ \\
\hline $\begin{array}{l}\% \text { of women in the community (PSU) endorsing marital } \\
\text { violence }\end{array}$ & & & $2.766 * * *(.759)$ \\
\hline $\begin{array}{l}\% \text { of women in the community (PSU) participating in } \\
\text { household decision-making }\end{array}$ & & & $1.686(.695)$ \\
\hline $\begin{array}{l}\% \text { of women in the primary sample unit supporting women } \\
\text { sexual right }\end{array}$ & & & $1.549 * *(.327)$ \\
\hline $\begin{array}{l}\% \text { of women in the community (PSU) that have access to } \\
\text { media. }\end{array}$ & & & $.94 I(.344)$ \\
\hline$\%$ of household in the primary sample unit with electricity & & & $.887(.184)$ \\
\hline Log-likelihood ratio & -6858.9286 & -6593.8344 & -6450.1826 \\
\hline
\end{tabular}

$*=p<0.05 ; * *=p<0.01 ; * * *=p<001 ; 1.000=$ reference category

Table 4: Random effects variance at the state and primary sampling unit levels: Contextual factors of intimate partner violence among Nigerian women, NDHS 2013

\begin{tabular}{|l|c|r|r|r|r|r|r|}
\hline \multirow{2}{*}{ Level } & Null Model & \multicolumn{2}{|c|}{ Model I: Compositional } & \multicolumn{2}{c|}{ Model 2: Compositional } & \multicolumn{2}{c|}{ Model 3: Compositional } \\
\cline { 2 - 8 } & Variance & Variance & $\begin{array}{c}\text { \% of change } \\
\text { from Null }\end{array}$ & Variance & $\begin{array}{c}\text { \% of change } \\
\text { from Null }\end{array}$ & Variance & $\begin{array}{c}\text { \% of change } \\
\text { from Null }\end{array}$ \\
\hline State & 1.152 & .482 & 58.2 & .388 & 66.3 & .260 & 77.4 \\
\hline PSU & 0.335 & .249 & 25.7 & .236 & 29.6 & .273 & 18.5 \\
\hline
\end{tabular}

I The first draft of the paper was completed when

Dr. Feyisetan was the Monitoring and Evaluation

Director, Evidence to Action (E2A) project. 